\title{
Identification of potential groundwater locations using geophysical data and fuzzy gamma operator model in Imo, Southeastern Nigeria
}

\author{
Zaidoon T. Abdulrazzaq ${ }^{1} \cdot$ Okechukwu E. Agbasi $^{2}$ (D) Nadia A. Aziz ${ }^{1} \cdot$ Sunday E. Etuk $^{3}$
}

Received: 2 July 2018 / Accepted: 17 June 2020 / Published online: 9 July 2020

(c) The Author(s) 2020

\begin{abstract}
Groundwater is among the most important resources of water supply of the worldwide population. The objective of this research is to select the most suitable drilling location of new groundwater wells, with a decision-making tool using geographic information system (GIS). The optimum location was evaluated based on the hydro-geoelectrical parameter derived from vertical electrical sounding (VES) including longitudinal conductance, aquifer thickness, aquifer resistivity, transmissivity, formation factor, and porosity. The analysis of the VES data revealed that the porosity values range from 1.8 to $21 \%$, the formation factor values vary between 0.0355 and 0.14 , the transmissivity values range from 3.4 to $6 \mathrm{~m}^{2} / \mathrm{day}$, the longitudinal conductance values vary from 3 to $4.6 \Omega^{-1}$, the aquifer thickness values range from 4.1 to $8.5 \mathrm{~m}$, the aquifer resistivity varies between 0.7 and $40 \Omega \mathrm{m}$. Hydro-geoelectrical data were integrated into GIS to precisely determine the best location for groundwater wells. Fuzzy liner membership was used to standardize the criteria layers; then, these layers were combined using fuzzy gamma overlay to produce the suitability map. The study area was classified into four classes: excluded, low suitability, moderate suitability, and high suitability. It is recommended that this method should be adopted by different governmental agencies involved in water resources management in Nigeria.
\end{abstract}

Keywords GIS · Hydro-geoelectrical parameter $\cdot$ Well site selection $\cdot$ Spatial analysis $\cdot$ Fuzzy gamma

\section{Introduction}

Water is an essential component in many aspects of human life, availability of a reliable water source is a vital necessity meant for maintainable advance both in domestic and in industrial usage. With the increase in human consumption of water due to the rapid growth of the world's population

Okechukwu E. Agbasi

agbasi.okechukwu@gmail.com

Zaidoon T. Abdulrazzaq

zaidoon.taha@live.com

Nadia A. Aziz

nadia_naa@yahoo.com

Sunday E. Etuk

sunetuk2002@yahoo.com

1 Directorate of Space and Communications, Ministry of Science and Technology, Baghdad 10070, Iraq

2 Department of Physics, Michael Okpara University of Agriculture, Umudike, Nigeria

3 Department of Physics, University of Uyo, Uyo, Nigeria and agricultural/industrial progress, a drastic decrease in the world's water resources has been observed, especially in arid and semiarid regions. The groundwater is a promising and important resource for offsetting natural water shortages in places where surface water is scarce. Groundwater is a natural water resource often subjected to severe human impact. Strategies are required to preserve optimum groundwater, so management of this vital natural resource has become a worldwide priority. The use of groundwater for irrigation has increased widely in countries with arid and semiarid climates due to the scarcity of rainfall (Zektser and Everett 2004), in addition to it being a renewable source, less exposed to pollution (Cosgrove and Loucks 2015), as well as the possibility of extracting it at higher rates than recharge rates (Alwan et al. 2019). However, random drilling of water wells may lead to depletion of groundwater aquifers, if this is not done according to a well-thought-out plan to select suitable well-drilling sites with good productivity. From this point, the planning for the selection of well sites for the purpose of optimizing groundwater investment must be developed. 
The possibility of developing a plan for selecting ideal drilling sites depends mainly on specific criteria that reflect the quality and quantity of groundwater that can be extracted from the aquifer. In this context, the geoelectrical measurements are applied to determine the thickness, depth of aquifer, and estimating its water quality and other criteria can be calculated from these measurements. These criteria can be combined using multi-criteria evaluation (MCE) to identify a suitable location.

Many geophysical methods were used in groundwater exploration, but the famous and often one is the vertical electrical sounding (VES) (Keller and Frischknecht 1970; Agbasi and Etuk 2016). Due to its low cost, easy to apply, and fast to get a result, it is correlated with the other methods. Besides, providing primary information and proposing the best suitable region for drilling low-cost wells (Ahmed et al. 2012; Abdulrazzaq et al. 2019), VES has demonstrated to be valuable in groundwater study; this technique has been extensively used in groundwater exploration to determine the depth to the water table, aquifer geometry, and groundwater feature by analyzing measured apparent resistivity field data (Aziz et al. 2018). In designing suitable groundwater management schemes in any geological environment, whose properties (physical and chemical) and spatial circulation institute the purpose of all hydro-geological and hydro-geophysical investigations (Abdulrazzaq 2011), the ecology of the subsurface resources is of importance. Groundwater flow in broken aquifers is very difficult, and accuracy in estimating the hydraulic parameters depends, in particular, on the hydraulic activity of fractures, which is location specific (Laouini et al. 2017), the electrical resistivity of the rock and minerals and includes fluids (Lowrie 1997).

GIS is a spatial database management system used to manage data from various sources. It is considered as an effective tool in site selection studies as data are stored, analyzed, and presented according to user-defined specifications (Aziz et al. 2020). MCD is a decision analysis approach that combines both qualitative and quantitative information by deconstructing their problems in systematic orders based on several criteria (Chan et al. 2008). Previous studies were used the MCE approach to assess the spatial distribution in the environmental problems (such as Jeong et al. 2013; Mileu and Queirós 2018; Gaikwad and Bhagat 2018; Wang et al. 2019). Other studies were used MCE as a decisionmaking tool in site selection (e.g., Abudeif et al. 2015; Gigović et al. 2017; Aziz et al. 2018; Alwan et al. 2020).

The purpose of this study is to select the optimum drilling location of new wells via GIS-based MCE as a decisionmaking tool. The optimum locations are selected depending on the hydro-geophysical parameters derived from VES data including aquifer resistivity, aquifer thickness, longitudinal conductance, transmissivity, formation factor, and porosity. The results of this study could be helpful in incompetent water management planning, in addition to various fields such as agricultural, livestock, and human livelihood.

\section{Study area}

The research area (Fig. 1) is situated along the Imo River and near the state capital of Abia. The requirement for groundwater is quite high due to the urban nature of the population in the study area, which they use for residential and commercial purposes. The research area is a complex geological environment in the state of Imo. Below the area lie the following stratigraphic units: the Benin Formation, the Ogwashi-Asaba Formation, the Bende-Ameki Formation, the Imo Shale Formation, the Nsukka Formation, and the Ajali Formation (Nwosu et al. 2013a). The Benin Formation constitutes rough-grained gravelly sandstones with moderate intercalation of shales and clay. Sand elements, usually coarse-grained, pebbly, and poorly sorted, consist of fine-grained sand lenses (Nwosu et al. 2013b). The Ogwashi-Asaba Formation consists of a continuous succession of clays, sands, and grits with brown coal layers. The Ameki Formation consists of grayish-gray sandstones, shales, and mudstones of interspersed granite. This formation, in effect, embeds the impenetrable lmo shale category classified in lithology by horizontal and perpendicular versions. The Imo shale of the Paleocene age is established during the subversive period that followed the Cretaceous period. The Nsukka Formation, Ajali Sandstones, and Nkporo Shales are activated in progression (Nwosu et al. 2013a).

\section{Materials and methods}

\section{Hydro-geophysical data}

The optimum groundwater well locations are selected based on the hydro-geoelectrical parameters derived from 14 VES data points distributed well to cover most of the study area as shown in Fig. 2. The hydro-geoelectrical parameters include aquifer resistivity, aquifer thickness, longitudinal conductance, transmissivity, formation factor, and porosity. These parameters represent the most influential parameters and reflect the quantity and quality of potential groundwater will be extracted from this site. Table 1 shows the dataset used in this study.

\section{Criteria layers standardization}

To combine the criteria layers, the first step is to standardize the layers into a uniform scale. Fuzzy liner membership (FLM) was used in this study to standardize all the layers. 


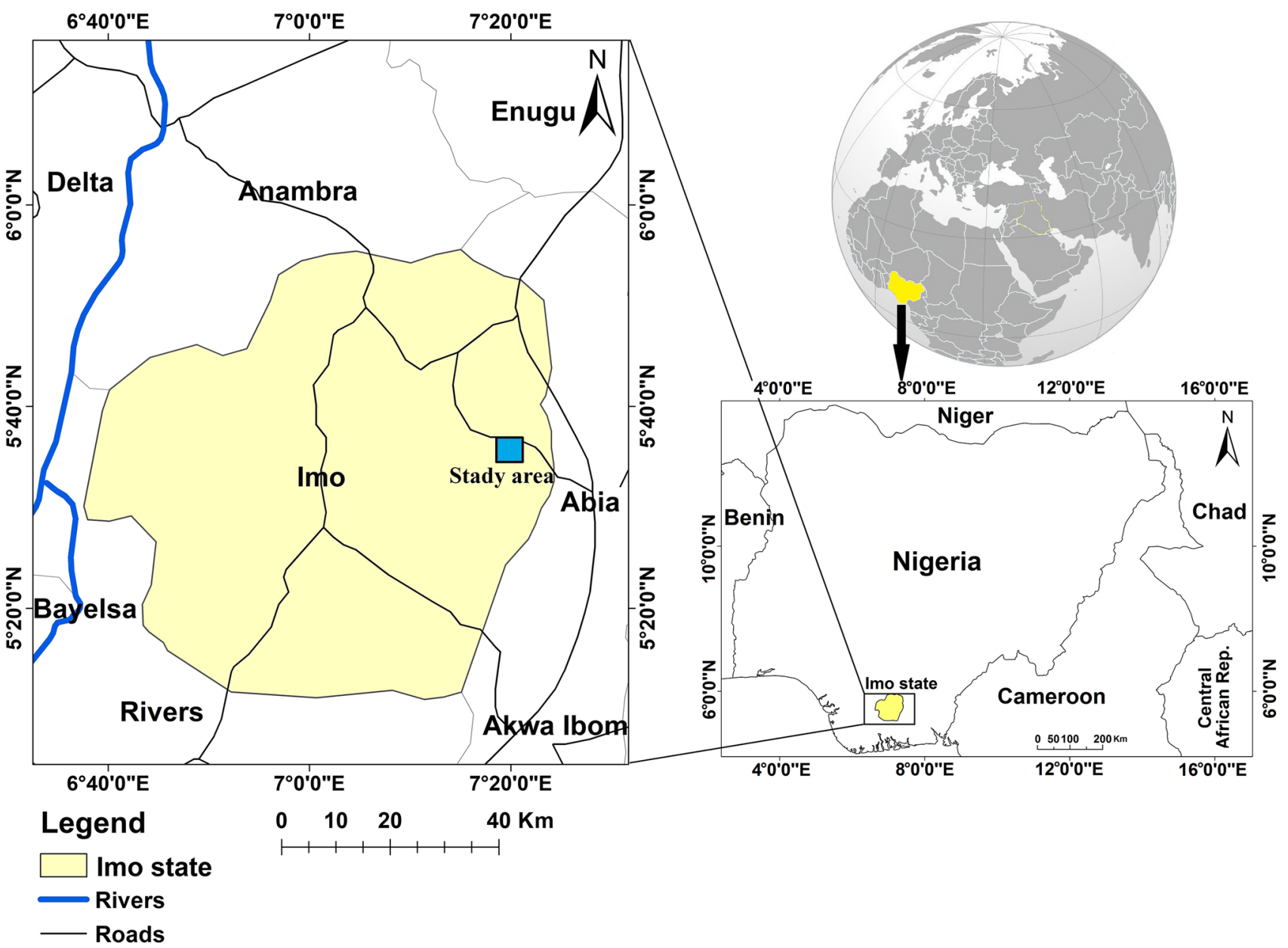

Fig. 1 Location of the study area

This step converts the layer into a scale with a value between zero and one, in which one indicates a suitable area, while zero indicates the unsuitable area. The fuzzy linear equation is (Benz et al. 2004):

$\mu(X)= \begin{cases}0 & \text { if } x<\min \\ 1 & \text { if } x>\max \\ \frac{(x-\min )}{(\max -\mathrm{min})} & \text { otherwise. }\end{cases}$

\section{Fuzzy overlay}

The final step to estimate the optimum location to drill groundwater wells combines all the criteria layers using the overlay processing. The suitability analysis was established using GIS methods dependent on several criteria layers. In this study, all the criteria layers were incorporated into ArcGIS 10.2 platform to make a map illustrating the appropriate location to drill a new groundwater wells using fuzzy overlay. Figure 3 explains the suitability model flowchart. Fuzzy overlay tool allows the analysis of the possibility of a phenomenon belonging to multiple sets in a multi-criterion overlay analysis. The overlay type lists the methods available to combine the data based on set theory analysis. ArcGIS software provides five methods, namely fuzzy and, fuzzy or, fuzzy product, fuzzy sum, and fuzzy gamma. The fuzzy gamma type is used in this study. The fuzzy gamma type is an algebraic product of fuzzy product and fuzzy sum, which are both raised to the power of gamma. The generalized function is as follows (Baidya et al. 2014): 


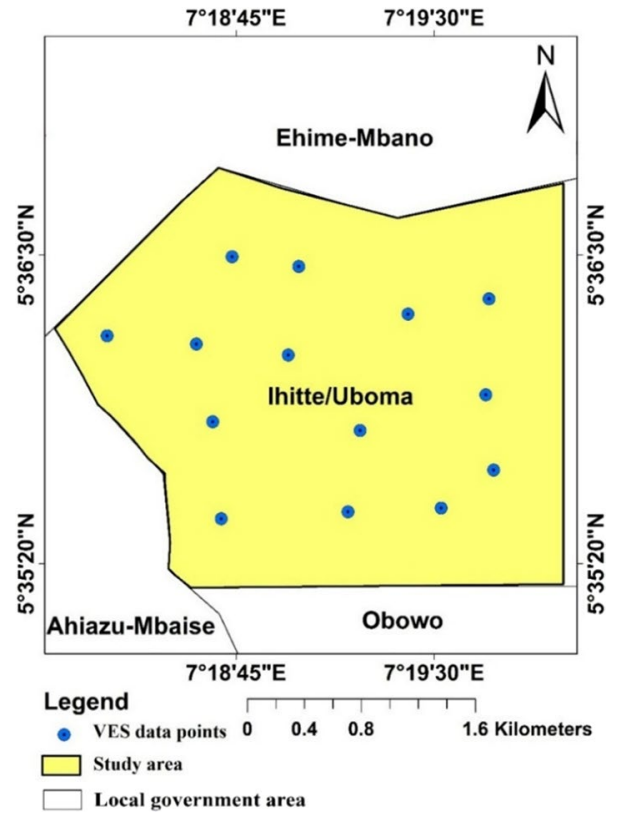

Fig. 2 The distribution of VES data points

\section{Results and discussion}

The input layers have been used to assess the outcomes from the integration between GIS and hydro-geophysical parameters. By intersection grouping technique in GIS (i.e., values of aquifer resistivity, aquifer thickness, longitudinal conductance, transmissivity, formation factor, and porosity), in this study, the Kriging method is used to interpolate the hydro-geophysical parameters layers as shown in Fig. 4. The porosity values range from 1.8 to $21 \%$, the formation factor values vary between 0.0355 and 0.14 , the transmissivity values range from 3.4 to $6 \mathrm{~m}^{2} /$ day, the longitudinal conductance values vary from 3 to $4.6 \Omega^{-1}$, the aquifer thickness values range from 4.1 to $8.5 \mathrm{~m}$, and the apparent resistivity varies between 0.7 and $40 \Omega \mathrm{m}$.

\section{Site suitability model}

The first step to generate the site suitability model has converted all the criterion layers into a uniform scale. This step is conducted using a fuzzy liner membership (FLM).

$\mu$ combination $= \begin{cases}\prod_{i=1}^{n} \mu_{i} & \text { (For fuzzy algebraic product) } \\ \prod_{i=1}^{n}\left(\mu_{i}-1\right) & (\text { For fuzzy algebraic sum }) \\ \text { (Fuzzy algebraic sum })^{\lambda} \times\left({\text { Fuzzy algebraic product })^{(1-\lambda)}} \text { (For fuzzy gamma) } .\right.\end{cases}$

Table 1 Hydro-geophysical data of aquifer

\begin{tabular}{|c|c|c|c|c|c|c|c|}
\hline Lat. & Long. & $\begin{array}{l}\text { Aquifer resistiv- } \\
\text { ity }(\Omega \mathrm{m})\end{array}$ & $\begin{array}{l}\text { Aquifer thick- } \\
\text { ness }(\mathrm{m})\end{array}$ & $\begin{array}{l}\text { Longitudinal con- } \\
\text { ductance }\left(\Omega^{-1}\right)\end{array}$ & $\begin{array}{l}\text { Transmissivity } \\
\left(\mathrm{m}^{2} / \text { day }\right)\end{array}$ & Formation factor & Porosity \\
\hline 5.604219 & 7.320564 & 1.350 & 3.890 & 2.881 & 2.684 & 0.074 & 3.674 \\
\hline 5.603579 & 7.320285 & 0.650 & 6.660 & 10.246 & 4.600 & 0.154 & 2.550 \\
\hline 5.601048 & 7.320285 & 2.550 & 12.910 & 5.063 & 8.894 & 0.039 & 5.050 \\
\hline 5.60344 & 7.317302 & 1.000 & 5.300 & 5.300 & 3.659 & 0.100 & 3.162 \\
\hline 5.593189 & 7.324169 & 1.340 & 10.410 & 7.769 & 7.183 & 0.075 & 3.661 \\
\hline 5.605148 & 7.31816 & 3.980 & 3.140 & 0.789 & 2.159 & 0.025 & 6.309 \\
\hline 5.605575 & 7.32846 & 31.370 & 0.210 & 0.007 & 0.139 & 0.003 & 17.712 \\
\hline 5.590968 & 7.327945 & 3.400 & 7.500 & 2.206 & 5.161 & 0.029 & 5.831 \\
\hline 5.599083 & 7.313697 & 5.930 & 4.650 & 0.784 & 3.189 & 0.017 & 7.701 \\
\hline 5.601859 & 7.318289 & 3.020 & 4.200 & 1.391 & 2.892 & 0.033 & 5.495 \\
\hline 5.605874 & 7.320306 & 4.300 & 11.570 & 2.691 & 7.953 & 0.023 & 6.557 \\
\hline 5.558128 & 7.326786 & 0.320 & 2.770 & 8.656 & 1.914 & 0.313 & 1.789 \\
\hline 5.586932 & 7.303011 & 40.240 & 1.780 & 0.044 & 1.168 & 0.002 & 20.060 \\
\hline 5.605041 & 7.335284 & 2.480 & 15.060 & 6.073 & 10.376 & 0.040 & 4.980 \\
\hline
\end{tabular}




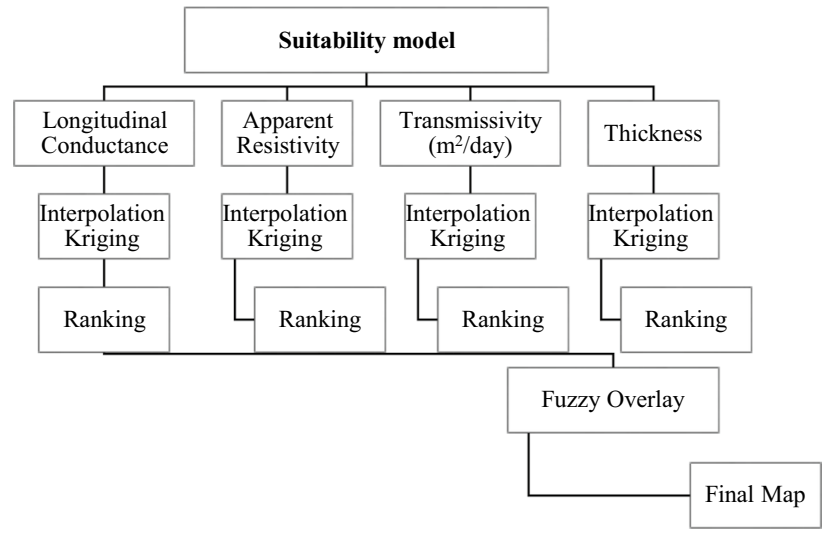

Fig. 3 The suitability model flowchart

Figure 5 shows the FLM for the six criteria layers used in this study. Finally, these criteria are combined and the suitability map is produced using fuzzy gamma overlay as shown in Fig. 6. The results map classified the study area into four classes, namely excluded, low suitability, moderate suitability, and high suitability. The total area and percentage of each class are calculated and illustrated in Table 2. The study was relevant that the southwestern part of the studied area is expected to be highly suitable to drill new groundwater wells according to the proposed criteria.

\section{Conclusion}

This study demonstrated the capabilities of GIS-based MCE in suitability analysis to choose suitable sites to drill new groundwater wells in Southeastern Nigeria. The application of groundwater suitability analysis directly helps the community to minimize the water crisis. GIS-based MCE and fuzzy logic are used to identify the optimum locations to drill new groundwater wells based on the geo-hydraulic parameters. The study area was classified into four classes: excluded, low suitability, moderate suitability, and high suitability. The study is relevant that the southwestern part of

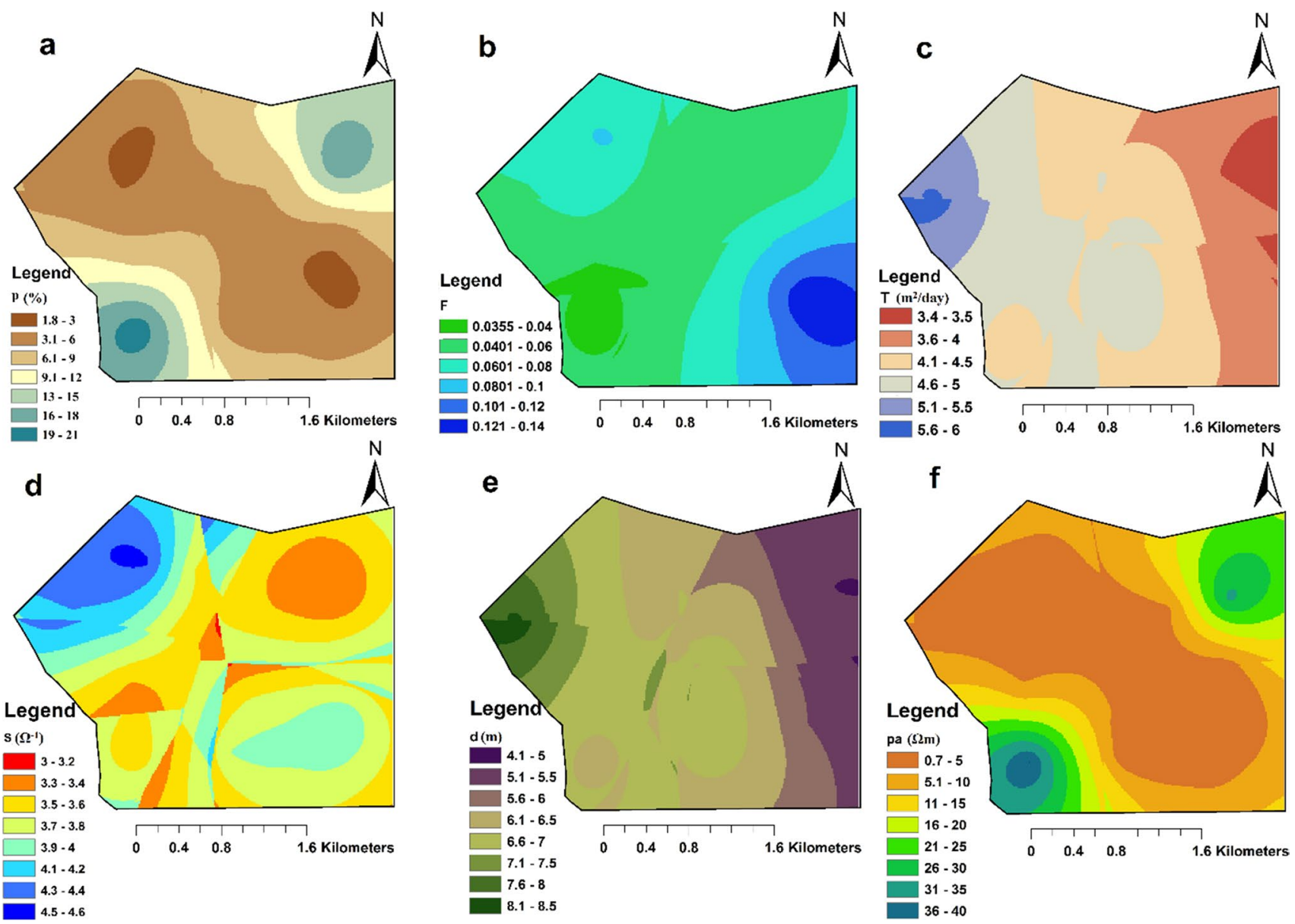

Fig. 4 Criteria layers interpolation using the Kriging method. a Porosity, b formation factor, $\mathbf{c}$ transmissivity, $\mathbf{d}$ longitudinal conductance, $\mathbf{e}$ aquifer thickness, and $\mathbf{f}$ aquifer resistivity 

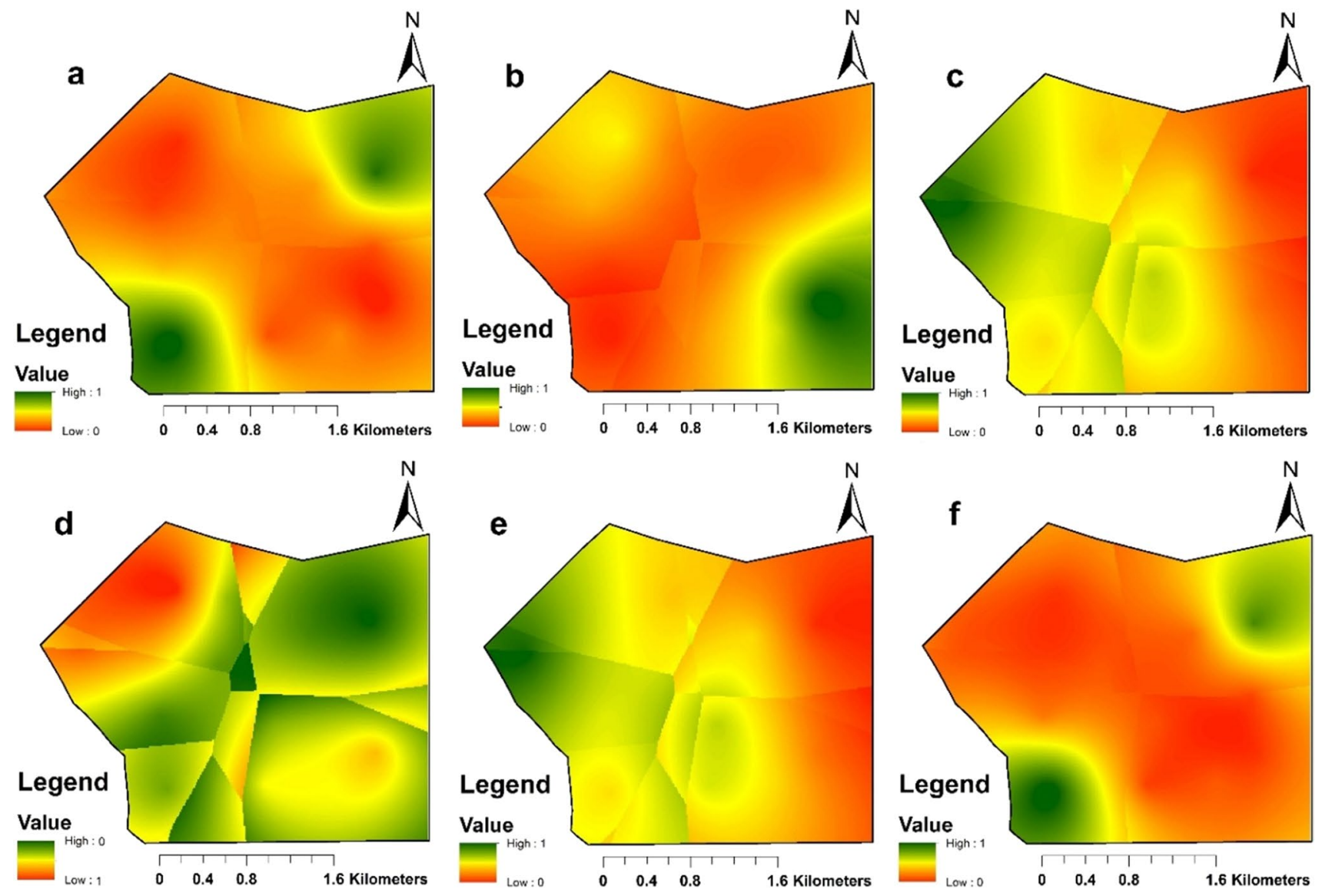

Fig. 5 Fuzzy liner membership for the criteria layers. a FLM for the porosity layer, b FLM for formation factor layer, c FLM for transmissivity layer, $\mathbf{d}$ FLM for longitudinal conductance layer, e FLM for thickness layer, and f FLM for aquifer resistivity layer

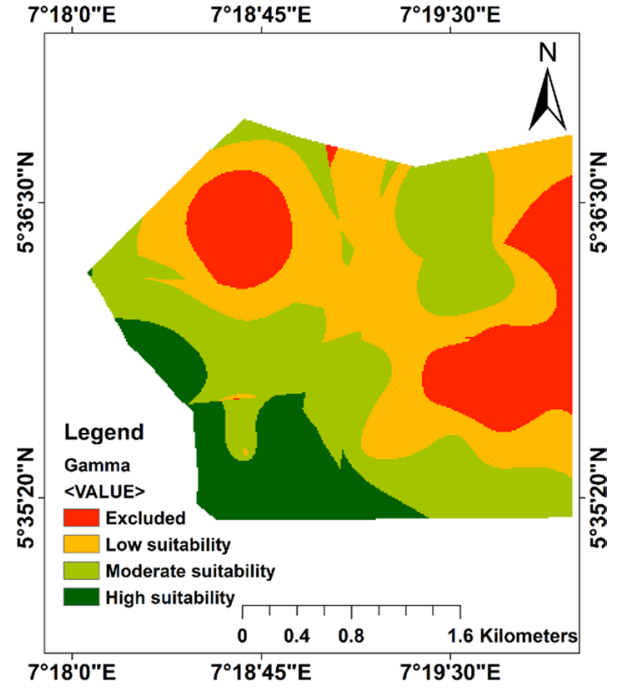

Fig. 6 Site suitability map using fuzzy gamma overlay
Table 2 The total area for each suitability class

\begin{tabular}{lcl}
\hline Class & Area $\left(\mathrm{km}^{2}\right)$ & Percentage \\
\hline Excluded & 2339.9 & 17.8 \\
Low & 4456.4 & 33.9 \\
Moderate & 4587.8 & 34.9 \\
High & 1761.5 & 13.4 \\
Total & $13,145.6$ & 100 \\
\hline
\end{tabular}

the studied area is expected to be highly suitable to drill new groundwater wells according to the proposed criteria. It is recommended that this method should be adopted by different governmental agencies involved in water resources management in Nigeria. Moreover, further studies in this field are recommended to provide a scientific base for an effective water management system in Nigeria. 
Funding No Funding.

\section{Compliance with ethical standards}

Conflict of interest There is no conflict of interest.

Open Access This article is licensed under a Creative Commons Attribution 4.0 International License, which permits use, sharing, adaptation, distribution and reproduction in any medium or format, as long as you give appropriate credit to the original author(s) and the source, provide a link to the Creative Commons licence, and indicate if changes were made. The images or other third party material in this article are included in the article's Creative Commons licence, unless indicated otherwise in a credit line to the material. If material is not included in the article's Creative Commons licence and your intended use is not permitted by statutory regulation or exceeds the permitted use, you will need to obtain permission directly from the copyright holder. To view a copy of this licence, visit http://creativecommons.org/licenses/by/4.0/.

\section{References}

Abdulrazzaq ZT (2011) Application of vertical electrical sounding to delineate and evaluate of aquifers characteristics in Baiji-Tikrit Basin. M.Sc. thesis, College of Science, University of Tikrit

Abdulrazzaq ZT, Al-Heety AJ, Shanshal ZM (2019) Integration of 1D and $2 \mathrm{D}$ electrical resistivity techniques to determine the thickness and extension of the main aquifer in Al-Rehaemia Area, Al-Najaf Governorate, Central Iraq. Iraqi Bull Geol Min 15(1):1-13

Abudeif AM, Abdel Moneim AA, Farrag AF (2015) Multicriteria decision analysis based on analytic hierarchy process in GIS environment for siting nuclear power plant in Egypt. Ann Nucl Energy 75:682-692. https://doi.org/10.1016/j.anucene.2014.09.024

Agbasi OE, Etuk SE (2016) Hydro-geoelectric study of Aquifer potential in parts of Ikot Abasi local government area, Akwa Ibom state, using electrical resistivity soundings. Int J Geol Earth Sci 2(4):43-44

Ahmed MM, Abdulrazzaq ZT, Salih SA (2012) Application of vertical electrical sounding to delineate and evaluate the hydrological conditions in Baiji-Tikrit Basin. In: Proceedings -6th edition of the international Congress GEO-TUNIS

Alwan IA, Karim HH, Aziz NA (2019) Groundwater aquifer suitability for irrigation purposes using multi-criteria decision approach in Salah Al-Din Governorate/Iraq. AgriEngineering 1:303-323. https://doi.org/10.3390/agriengineering 1020023

Alwan IA, Aziz NA, Hamoodi MN (2020) Potential water harvesting sites identification using spatial multi-criteria evaluation in Maysan Province, Iraq. ISPRS Int J Geo-Inf 9:235. https://doi. org/10.3390/ijgi9040235

Aziz NA, Hasan RH, Abdulrazzaq ZT (2018) Optimum site selection for groundwater wells using integration between GIS and hydrogeophysical data. Eng Technol J 36(6 Part A):596-602. https:// doi.org/10.30684/etj.36.6A.1

Aziz NA, Abdulrazzaq ZT, Mansur MN (2020) GIS-based watershed morphometric analysis using DEM data in Diyala River, Iraq. Iraqi Geol J 53(1C):36-49
Baidya P, Chutia D, Sudhakar S, Goswami C, Goswami J, Saikhom V, Singh PS, Sarma KK (2014) Effectiveness of fuzzy overlay function for multi-criteria spatial modeling - a case study on preparation of land resources map for Mawsynram Block of East Khasi Hills District of Meghalaya, India. J Geogr Inf Syst 6:605-612. https://doi.org/10.4236/jgis.2014.66050

Benz UC, Hofmann P, Willhauck G, Lingenfelder I, Heynen M (2004) Multi-resolution, object-oriented fuzzy analysis of remote sensing data for GIS-ready information. ISPRS J Photogramm 58(34):239-258. https://doi.org/10.1016/j.isprsjprs.2003.10.002

Chan F, Kumar N, Tiwar M, Lau H, Choy K (2008) Global supplier selection: a fuzzy-AHP approach. Int J Prod Res 46:3825-3857. https://doi.org/10.1080/00207540600787200

Cosgrove WJ, Loucks DP (2015) Water management: current and future challenges and research directions. Water Resour Res 51:4823-4839. https://doi.org/10.1002/2014WR016869

Gaikwad RD, Bhagat VS (2018) Multi-criteria prioritization for sub-watersheds in Medium River Basin using AHP and influence approaches. Hydrospatial Anal 2(1):61-82. https://doi. org/10.21523/gcj3.18020105

Gigović L, Pamučar D, Božanić D, Ljubojević S (2017) Application of the GIS-DANP-MABAC multi-criteria model for selecting the location of wind farms: a case study of Vojvodina, Serbia. Renew Energy 103:501-521. https://doi.org/10.1016/j.renen e.2016.11.057

Jeong JS, García-Moruno L, Hernández-Blanco J (2013) A site planning approach for rural buildings into a landscape using a spatial multi-criteria decision analysis methodology. Land Use Policy 32:108-118. https://doi.org/10.1016/j.landusepol.2012.09.018

Keller GV, Frischknecht FC (1970) Electrical method in geophysical prospecting. Pergamon Press, Oxford

Laouini G, Etuk SE, Agbasi OE (2017) Delineation of aquifers using Dar Zarrouk parameters in parts of Akwa Ibom, Niger Delta, Nigeria. J Hydrogeol Hydrol Eng 6:1. https://doi.org/10.4172/23259647.1000151

Lowrie W (1997) Fundamentals of geophysics. Cambridge University Press, New York

Mileu N, Queirós M (2018) integrating risk assessment into spatial planning: riskote decision support system. ISPRS Int J Geo Inf 7:184. https://doi.org/10.3390/ijgi7050184

Nwosu LI, Ekine AS, Nwankwo CN (2013a) Evaluation of groundwater potential from pumping test analysis and vertical electrical sounding results: case study of Okigwe District of Imo State Nigeria. Pac J Sci Technol 14(1):536-548

Nwosu LI, Nwankwo CN, Ekine AS (2013b) Geoelectric investigation of the hydraulic properties of the aquiferous zones for evaluation of groundwater potentials in the complex geological area of Imo State, Nigeria. Asian J Earth Sci 6:1-15. https://doi.org/10.3923/ ajes.2013.1.15

Wang Y, Hong H, Chen W, Li S, Pamučar D, Gigović L, Drobnjak S, Tien Bui D, Duan H (2019) A hybrid GIS multi-criteria decisionmaking method for flood susceptibility mapping at Shangyou, China. Remote Sens 11:62. https://doi.org/10.3390/rs11010062

Zektser IS, Everett L (2004) Groundwater resources of the world: and their use. IhP Series on Groundwater, No. 6. UNESCO, Paris

Publisher's Note Springer Nature remains neutral with regard to jurisdictional claims in published maps and institutional affiliations. 